\title{
NORMAS PARA SUBMISSÃO DE TRABALHOS
}

A revista Leia Escola é um periódico semestral do Programa de Pós-Graduação em Linguagem e Ensino da Unidade Acadêmica de Letras da Universidade Federal de Campina Grande, que aceita para publicação as seguintes contribuições: artigos inéditos, resultados de pesquisas no âmbito da Linguística Aplicada ao ensino de línguas e de literaturas, bem como resenhas críticas de publicações nas áreas de Letras e Linguística.

Os interessados em publicar artigos na Leia Escola devem enviar os trabalhos para o e-mail: leiaescola2010@gmail.com, em dois arquivos. No $1^{\circ} \mathrm{ar}-$ quivo, deve constar o texto completo com a devida autoria (máximo de dois autores), filiação acadêmica, endereço, telefones para contato, e-mail. No $2^{\circ}$ arquivo deve constar o texto sem informação que identifique a autoria.

Os trabalhos devem conter as seguintes características gerais de formatação: página A-4, fonte Times New Roman, tamanho 12, margens 2,5 cm, espaço simples, alinhamento justificado, em documento do Word versão 97-2003, parágrafos com recuo de $1,5 \mathrm{~cm}$.

O trabalho completo deve ser apresentado, considerando os seguintes itens:

1. O título centralizado, no topo da página, tamanho 14, caixa alta e negrito.

2. $\mathrm{O}(\mathrm{s})$ nome(s) do(s) autor(es), a dois espaços simples abaixo do título, alinhado à direita, tamanho 11, indicado(s) por asterisco, em nota de rodapé, a(s) titulação(ões), filiação(ões) institucional(ais) e e-mail para contato. Alunos de mestrado e doutorado deverão publicar em coautoria com um professor doutor vinculado a uma IES.

3. O termo Resumo, em negrito, tamanho 10, a dois espaços simples abaixo do(s) nome(s) do(s) autor(es), seguido por dois pontos e um texto digitado em parágrafo único, tamanho 10 , espaço simples, alinhamento justificado, contendo de 100 a 120 palavras, em português. 
4. A expressão Palavras-chave, em negrito, tamanho 10, abaixo da última linha do Resumo, seguida de dois pontos e de três a cinco palavras, separadas entre si por ponto e finalizadas também por ponto.

5. O termo Abstract, em negrito, a um espaço simples abaixo das Palavras-chave, seguido por dois pontos e uma versão em língua inglesa do resumo, contendo as mesmas características estruturais descritas no item 3 .

6. A palavra Keywords, em negrito, seguida de dois pontos e de três a cinco palavras em língua inglesa, abaixo da última linha do Abstract, contendo as mesmas características estruturais descritas no item 4.

7. Divisões internas do corpo do trabalho, grafadas na mesma fonte e corpo do texto, em negrito, alinhadas à esquerda e numeradas a partir de 1. Exemplo: 1 Introdução.

8. A primeira divisão interna a dois espaços simples da palavra Keywords e o parágrafo inicial a um espaço simples da primeira divisão interna.

9. As demais divisões internas, incluindo as Referências (assim grafadas), a dois espaços simples do parágrafo precedente, seguidas pelo texto a um espaço simples.

10. Citações com até três linhas inseridas no corpo do texto, entre aspas duplas, complementadas da seguinte forma: a) para fazer referências às idéias do autor: ... conforme Deleuze (1974, p. 15); b) para referências após a citação: ... (DELEUZE, 1974, p. 15); c) para parafrasear as idéias do autor: ... (cf. DELEUZE, 1974). (Não usar expressões como "idem" ou “idem, ibidem”).

11. Citações com mais de três linhas apresentadas em margem própria, a um espaço simples dos parágrafos anterior e poste- 
rior, com recuo de $4,0 \mathrm{~cm}$ da margem esquerda, espaço simples, corpo 11, sem aspas, nem itálico, seguidas da referência entre parênteses, conforme exemplo: (DELEUZE, 1974, p. 15).

12.As notas explicativas (se necessário) inseridas ao final de cada página, numeradas a partir de 1 . Não utilizar as notas explicativas para Referências.

13.Itálico para ênfase, termos estrangeiros, neologismos, títulos de livros e periódicos.

14. Tabelas, gráficos, quadros ou ilustrações (se houver) numerados e identificados, com título ou legenda, tamanho 10 (apenas as iniciais em maiúsculas), e referenciados, ao longo do texto, de forma abreviada: Tab. 1, Tab. 2, Fig. 1, Fig. 2 etc.

15.Referências, ao final do texto, em ordem alfabética, sem numeração das entradas, alinhamento justificado, em espaço simples e separadas entre si por espaço simples. (Ver alguns exemplos após o item 16).

16.A quantidade de, no mínimo 10 e, no máximo 20 páginas, englobando todos os itens acima, como também as Referências. Não incluir anexos.

\section{Alguns exemplos de Referências:}

Livro: SOBRENOME DO AUTOR, Nome abreviado. Título do livro (em itálico): (subtítulo, se houver). Edição. Local de publicação: Editora, Data. Exemplo: BAKHTIN, M. Marxismo e filosofia da linguagem. 11. ed. São Paulo: Hucitec, 2004.

Capítulo de livro: SOBRENOME DO AUTOR DO CAPÍTULO, Nome abreviado. Título do capítulo: (subtítulo, se houver). In: SOBRENOME DO AUTOR DO LIVRO, Nome abreviado. Título do livro (em itálico): (subtítulo, se houver). Local de publicação: Editora, Data, páginas inicial 
e final do capítulo.

Exemplo: THERRIEN, J. O saber do trabalho docente e a formação do professor. In: SHIGUNOV NETO, A.; MACIEL, L. S. B. (Org.). Reflexões sobre a formação de professores. Campinas: Papirus, 2002, p. 103-114.

Artigo de periódico: SOBRENOME DO AUTOR, Nome abreviado. Título do artigo: (subtítulo, se houver). Nome do periódico (em itálico), local de publicação, número do volume, número do fascículo, páginas inicial e final do artigo, mês e ano da publicação.

Exemplo: GURGEL, C. Reforma do Estado e segurança pública. Política e Administração, Rio de Janeiro, v. 3, n. 2, p. 15-21, set. 1997.

Trabalho Acadêmico: SOBRENOME DO AUTOR, Nome abreviado. Título (em itálico): (subtítulo, se houver). Local e ano da defesa ou da apresentação. Número de folhas ou volumes. Categoria (Tese, Dissertação ou Monografia) (Grau Acadêmico, entre parênteses) - Vínculo Acadêmico/ Instituição de Ensino.

Exemplo: CARRARA, A. A. Agricultores e pecuária na capitania de Minas Gerais (1674-1807). Rio de Janeiro, 1997. 230f. Tese (Doutorado em História) - Instituto de Filosofia e Ciências Humanas, Universidade Federal do Rio de Janeiro.

Observação: Para as demais regras não esclarecidas aqui, seguir normas atualizadas da ABNT. 